\title{
SUCESSÃO DOS COMPANHEIROS: ANÁLISE DA ATUAL INTERPRETAÇÃO DOUTRINÁRIA E JURISPRUDENCIAL
}

\begin{abstract}
Luiza Freccia ${ }^{1}$
Resumo: O tema sobre o qual versa este artigo pertence à seara do direito sucessório, especialmente a sucessão dos companheiros que vivem em união estável, relação esta reconhecida como entidade familiar pela própria ordem constitucional brasileira, desde 1988, mas que não encontra unanimidade, tanto na doutrina quanto na jurisprudência, sobre a participação do companheiro na divisão da herança do de cujus. Nesse contexto, a presente pesquisa visa identificar se a sucessão dos companheiros fere os dispositivos constitucionais, em decorrência da desigualdade de tratamento do casamento e da união estável na esfera do direito sucessório.
\end{abstract}

Palavras-chave: União estável. Casamento. Direito sucessório. (In)constitucionalidade.

\section{INTRODUÇÃO}

A partir da Constituição da República Federativa do Brasil (CRFB), promulgada em 1988, a união estável foi reconhecida como entidade familiar, sendo equiparada, por meio do artigo $226, \S 3^{\circ}$, à relação existente no casamento para fins de proteção estatal.

1 Aluna do Modulo I do Curso de Preparação à Magistratura - ESMESC; Assessora Jurídica no Gabinete do Des. Jorge Luis Costa Beber - TJSC; E-mail: luizafreccia@hotmail.com. Orientação: Profa Patrícia Fontanella, Msc. 
Dessa constatação surge, então, a questão-problema que dirige a presente investigação: se a união estável e o casamento devem ser provenientes do intuito de constituir família, considerados constitucionalmente como entidades familiares, por que não equipará-los no âmbito sucessório?

Dentro desse contexto, a pesquisa visa identificar se a sucessão dos companheiros fere os dispositivos constitucionais, em decorrência da desigualdade de tratamento do casamento e da união estável na esfera do direito sucessório. Para atingir esse fim, será necessário primeiramente: conhecer a entidades familiares e as disposições constitucionais respectivas; estudar o direito sucessório dos cônjuges e dos companheiros no Código Civil (CC) brasileiro; e investigar a interpretação doutrinária e jurisprudencial atual sobre o tema da sucessão dos companheiros.

\section{ENTIDADES FAMILIARES E CONSTITUIÇÃO FEDERAL: A MUDANÇA DO PARADIGMA FAMILIAR NO BRASIL}

Com a modificação da sociedade, a evolução dos costumes e das instituições sociais e jurídicas, fez-se necessária a reformulação do conceito de família, justo para valorizar e proteger esforços de um núcleo familiar construído ao longo de toda uma vida e que eram deixados de lado pelo legislador (MONTEIRO, 2008, p. 17).

Pluralizaram-se as origens da formação da família de modo que, constitucionalmente, foram consideradas três espécies de entidades familiares: a constituída a partir do casamento civil, ou religioso com efeitos civis (CRFB, art. 226, §§ $1^{\circ}$ e $2^{\circ}$ ); a que surge por meio da união estável entre o homem e a mulher (CRFB, art. 226, § 3o); e, por fim, a formada por qualquer dos pais e seus descendentes (CRFB, art. 226, § 4\%); garantindo a todos plena proteção do Estado (MORAES, 2006, p. 2214).

O grande questionamento doutrinário a respeito do artigo 226 da CRFB alude às entidades familiares por ele determi- 
nadas. A discussão reside em vislumbrar se estaria o legislador constituinte engessando o conceito de família às três modalidades previstas, ou se estas seriam simplesmente hipóteses exemplificativas.

Segundo Paulo Lobo (2008, p. 60), a interpretação dominante da norma é no sentido de reconhecer apenas os tipos de família elencados pelo artigo. No entanto, essa corrente ainda é subdividida em duas partes. A primeira defende a hierarquia dos institutos em função do $§ 30$ do art. 226, interpretado de forma que o casamento estaria acima dos demais. Já a segunda declara que há plena igualdade entre os três modelos previstos, amparada pela ideia de que a opção da forma familiar mais adequada cabe aos conviventes, determinada pelo princípio da liberdade de escolha.

Contudo, há coexistência de outra vertente, já confirmada inclusive pelo Superior Tribunal de Justiça (STJ), que vem defendendo que os direitos familiares são reconhecidos também às novas formações, ignorando a taxatividade das entidades supracitadas (TARTUCE, 2008, p. 47).

A inclusão dessas entidades familiares não está explicitamente contemplada na Carta Magna brasileira, porém sua ampliação interpretativa está fundada no fato de que o texto do legislador constituinte prestou tutela jurisdicional à família, sem qualquer "cláusula de exclusão" que determinasse que sua formação é, obrigatoriamente, de um jeito ou de outro (LOBO, 2008, p. 60).

Para o mesmo norte caminhou a reforma do Código Civil, em 2002, a partir do qual "o direito de família passou a regular não só as relações oriundas de casamento, mas também aquelas originárias de união estável, como se verifica no título a essa espécie de família destinado - arts. 1.723 a 1.727”, confirmando, assim, uma quebra do dito paradigma familiar (MONTEIRO, 2009, p. 4).

As alterações do texto constitucional e do diploma civilista visam acolher uma nova concepção da função social da família 
no direito brasileiro, que tem como objeto principal a priorização dos vínculos afetivos (GONÇALVES, 2009).

O reconhecimento da união estável e das famílias monoparentais, inovando a redação constitucional, em contrapartida aos ordenamentos jurídicos brasileiros anteriores, surge como aspecto de interesse público e não somente uma "união de afeto de interesse privado”, eis que tais concepções também são consideradas entidades fundamentais na composição da sociedade, como outrora era papel exclusivo do casamento (BONAVIDES, 2009).

Segundo Carlos Roberto Gonçalves (2009, p. 555), a principal característica da união estável é a informalidade. A simples existência da vida em comum é o início para o seu reconhecimento, diferente do casamento, que é "precedido de um processo de habilitação, com publicação dos proclamas e inúmeras outras formalidades".

Quando a CRFB preceitua que a conversão da união estável em casamento deve ser facilitada, não está criando nenhum padrão de hierarquia. Tal previsão se limita a dispensar algumas exigências que seriam necessárias para a efetivação do casamento, apenas beneficiando os companheiros, não significando que o casamento possui alguma preferência sobre a união estável (VELOSO, 2010).

Patrícia Fontanella (2006, p. 51) ainda anota que "há a presunção de esforço comum de todos os bens adquiridos na constância da união, na ausência de estipulação entre as partes”.

Da mesma forma que é aplicada ao matrimônio, a união estável não será constituída se presentes os impedimentos previstos pelo art. 1.521 do CC, exceto para a hipótese do inciso VI do mencionado artigo, na hipótese de os conviventes estarem separados de fato. Já as causas suspensivas do casamento (art. 1.523, CC) não são empecilho para o reconhecimento da união estável, restando à doutrina a discussão apenas no que tange à aplicação da separação obrigatória de bens a estes casos (art. 1.641, CC), em face da omissão da legislação em vigor (2006, p. 51). 
Importante registrar que, recentemente, o Supremo Tribunal Federal (STF), ao julgar demandas como as propostas na Ação Direta de Inconstitucionalidade (ADI) 4277 e na Arguição de Descumprimento de Preceito Fundamental (ADPF) 132, reconheceu a união entre pessoas do mesmo sexo como entidade familiar, desde que preenchidos os mesmos requisitos impostos para a caracterização da união estável entre o homem e a mulher (STF, 2011).

A decisão foi proferida no sentido de eliminar qualquer interpretação do art. 1.723 do CC que limite o reconhecimento da união entre pessoas do mesmo sexo como entidade familiar, baseado principalmente na disciplina do art. 3o, inciso IV, da CRFB, que veda qualquer discriminação em virtude de sexo, raça e cor (STF, 2011). Tal inovação demonstra, cada vez mais, a adequação dos preceitos legais à realidade da sociedade contemporânea.

Inobstante as modernizações da legislação vigente e a consequente adaptação às necessidades da sociedade, o casamento civil continua sendo o meio pelo qual os laços afetivos se tornam mais fortes aos olhos da justiça. Abrangendo efeitos pessoais, sociais e patrimoniais, a relação proveniente do casamento é amplamente amparada em função da criação de direitos e deveres mútuos entre os nubentes (OLIVEIRA, 2003, p. 129).

Dessa maneira, a reforma do ordenamento jurídico, no que tange à abrangência da proteção das entidades familiares, "procura harmonizar as normas abstratas do ordenamento constitucional com a realidade subjacente da vida social" (SILVA, 2008, p. 853).

\section{O DIREITO SUCESSÓRIO DOS CÔNJUGES NO CÓDIGO CIVIL}

A partir das alterações promovidas e gravadas no atual ordenamento civil, no casamento, havendo o silêncio das partes, o regime que prevalece é o da comunhão parcial. Essa disposição 
fez surgir a necessidade de dar um maior amparo ao cônjuge, que ficaria desprotegido e prejudicado com um eventual falecimento do outro, já que o recebimento da meação não mais era direito certo do cônjuge supérstite. Vem daí a justificativa para a sua inclusão no rol dos herdeiros necessários, estabelecido pelo art. 1.845, concedendo-lhe uma melhor posição (WALD, 2007, p. 20).

Da leitura da segunda parte do inciso I do art. 1.829 do $\mathrm{CC}$, denota-se que o legislador abre exceções à concorrência do cônjuge com os descendentes, justamente em decorrência do regime de bens.

Nos casos dos casados pelo regime de separação obrigatória (previsto no art. 1.641 e não no art. 1.640, como indicado no texto civil), no regime da comunhão universal ou no regime da comunhão parcial de bens, na hipótese de o de cujus não ter deixado bens particulares, não há a participação do cônjuge sobrevivo na concorrência da primeira classe da ordem de vocação hereditária (CAHALI, 2007, p. 169).

Para Giselda Maria Fernandes Novaes Hironaka (2004, p. 94), o raciocínio do legislador é o de que, no casamento constituído pelo regime da comunhão universal de bens, "a comunhão patrimonial já se operara desde a celebração das núpcias”, por isso a sua exclusão na concorrência com os descendentes. Esse entendimento também alude ao fato de que o cônjuge já é amplamente amparado pelo recebimento da meação, composta por metade dos bens comuns do casal.

Os cônjuges que constituíram união sob o regime da separação obrigatória são impedidos por lei de "estabelecer regime patrimonial diverso" (2004, p. 95), portanto, não pode haver, de forma alguma, convocação para concorrência nesse primeiro momento, eis que existem causas específicas para tal vedação legal e sua admissão burlaria o sistema legal.

Com se vê, não houve qualquer exceção ou ressalva no que tange ao regime da separação convencional de bens, consequentemente é permitida a concorrência com os descendentes, bem 
como no casamento regido pela participação final dos aquestos (GONÇALVES, 2009, p. 163).

Objeto de grande controvérsia, entretanto, é a interpretação do final do inciso I do art. 1.829 do CC, cuja redação ambígua aborda a exclusão do cônjuge sobrevivente no caso de inexistência de bens particulares do falecido.

Do Enunciado 270, da III Jornada de Direito Civil, organizada pelo Conselho da Justiça Federal, deriva a primeira corrente doutrinária, onde a art. 1.829 , inc. I, só assegura ao cônjuge sobrevivente o direito de concorrência com os descendentes do autor da herança quando casados no regime da separação convencional de bens, ou então, se casados nos regimes da comunhão parcial ou participação final nos aqüestos, o falecido possuísse bens particulares, circunstância em que a concorrência se restringe a tais bens, devendo os bens comuns (meação) ser partilhados exclusivamente entre os descendentes (BRASIL, 2011).

Giselda Maria Fernandes Novaes Hironaka (2004, p. 94), acompanhando grande parte da doutrina, defende a interpretação que considera que o dispositivo limita a concorrência do cônjuge supérstite, que era casado sob o regime da comunhão parcial de bens, com os descendentes, exclusivamente aos bens particulares do de cujus. Para a autora, o raciocínio do legislador estaria baseado no fato de que os bens que pertenciam ao casal já são divididos em função da dissolução da sociedade conjugal em decorrência da morte. Já no que tange aos bens particulares do autor da herança, são eles partilhados pelos herdeiros a título de sucessão causa mortis, inclusive o cônjuge já que é considerado herdeiro necessário.

Maria Helena Diniz (2010, p. 126) adota posicionamento diverso. A análise da doutrinadora, no que tange à concorrência do cônjuge sobrevivente com os descendentes, é que também deve ser observado se o falecido possuía bens particulares, se casado no regime comunhão parcial, "embora sua participação incida sobre todo o acervo hereditário" e não somente no patri- 
mônio particular do de cujus. A doutrinadora ainda alega que tal consideração deve ser adotada em função do princípio da operabilidade, com o fim de facilitar o cálculo da partilha, bem como da indivisibilidade da herança. E, ainda, que o resguardo de parcela do acervo hereditário ao cônjuge supérstite que foi ascendente dos demais herdeiros não seria compatível com uma eventual exclusão da concorrência no que se refere à totalidade dos bens do autor da herança, além do que o cônjuge é considerado herdeiro necessário.

Há, ainda, um terceiro entendimento, ao qual se filia Maria Berenice Dias (2011), que opina no sentido de que a sucessão do cônjuge fica excluída na hipótese de o falecido ter deixado bens particulares, concorrendo com os descendentes apenas com os bens comuns. O raciocínio da autora é o seguinte: deve ser respeitado o que foi pactuado pelos nubentes, mantendo a incomunicabilidade dos bens particulares ao cônjuge sobrevivente, como já era a forma vigente durante a união do casal (DIAS, 2011).

O STJ estabelece um quarto posicionamento baseado "na idéia de que a vontade do cônjuge, manifestada no casamento, deve ser tomada em consideração também no momento de interpretar as regras sucessórias” (STJ, 2011).

A Corte Superior de Justiça preserva-se "o regime da comunhão parcial de bens” no momento que é concedido ao cônjuge sobrevivente o direito à meação, "além da concorrência hereditária sobre os bens comuns, haja ou não bens particulares, partilháveis, estes unicamente entre os descendentes” (STJ, 2011).

Ainda, no que tange à concorrência na primeira classe da ordem de vocação hereditária, impende ressaltar que com a morte, e havendo descendentes do falecido, a divisão patrimonial deverá ocorrer entre os filhos em concorrência com o cônjuge supérstite, cabendo a este "quinhão igual ao dos que sucederem por cabeça, não podendo a sua quota ser inferior à quarta parte da herança, se for ascendente dos herdeiros com que concorrer" (art. 1.832, CC). 
$\mathrm{Na}$ hipótese de filiação híbrida, ou seja, a existência de descendentes exclusivos do autor da herança e comuns com o cônjuge supérstite, a doutrina majoritária entende que a regra estabelecida pelo art. 1.832 do CC, reservando uma quarta parte da herança ao cônjuge sobrevivente, não é aplicável. O patrimônio é dividido igualmente, como se todos fossem herdeiros exclusivos do falecido (VELOSO, 2006, p. 45).

Questão igualmente importante se refere à inexistência de herdeiros na classe dos descendentes. Nesta hipótese, são chamados a suceder os ascendentes do falecido em concorrência com o cônjuge sobrevivente (art. 1.836 do CC). Todavia, na concorrência com os ascendentes não mais se apresentam as restrições decorrentes do regime de bens, ou seja, independentemente do regime patrimonial em que o viúvo ou viúva era casado com o de cujus, mesmo que já tenha recebido sua meação (VELOSO, 2010, p. 41).

Ora, de acordo com o art. 1.837 do CC, caberá ao cônjuge sobrevivente um terço da herança se concorrer com os ascendentes em primeiro grau e metade se concorrer com apenas um ascendente ou se for maior o grau de parentesco entre o falecido e os ascendentes.

É importante salientar que não há direito de representação na linha ascendente, razão pela qual, "havendo um único genitor vivo, não se devem convocar os avós, pais do genitor falecido, para representar seu filho na sucessão" (HIRONAKA, 2004, p. 97).

$\mathrm{Na}$ falta de descendentes e ascendentes, o cônjuge supérstite é considerado o único herdeiro legítimo, e não mais concorrente, cabendo-lhe a totalidade do acervo hereditário (art. 1.838 do CC), independentemente do regime de bens do casamento. Já as condições legais estabelecidas no art. 1.830 do mesmo diploma civil, continuam sendo requisitos que devem ser observados para que o cônjuge sobrevivente tenha o seu direito sucessório reconhecido (VELOSO, 2010, p. 89). 
De qualquer forma, o cônjuge herdeiro tem resguardada a legítima, por força do estabelecido nos arts. 1.845 e 1.846 do CC, eis que é considerado herdeiro necessário. Contudo, não se pode esquecer que o falecido poderá ter disposto em testamento até metade de seus bens, hipótese em que o cônjuge sobrevivente irá receber o equivalente ao que não foi consignado no testamento.

Além da posição privilegiada em relação aos demais parentes do falecido, o cônjuge supérstite tem, a seu favor, o direito real de habitação, instituído pelo art. 1.831 do CC, o qual garante a manutenção da residência da família, desde que seja o único imóvel dessa natureza a inventariar.

No direito real de habitação, da mesma forma, o regime de bens não interfere e o cônjuge favorecido não perde a meação e o quinhão hereditário em função deste benefício, desde que preenchidas as exigências estabelecidas no artigo suso mencionado.

De acordo com Francisco Cahali (2007, p. 172), "a habitação deferida em favor do viúvo é um direito personalíssimo e resolúvel”, o que limita os direitos da propriedade já que não cabe a fruição ampla, como, por exemplo, a possibilidade de alugar. O direito compreende a garantia ao cônjuge de "continuar utilizando diretamente a residência, sem qualquer ônus perante os titulares do domínio".

Em relação à extinção do direito real de habitação, encontra-se certa discussão doutrinária. Para doutrinadores como Francisco Cahali e Silvio Rodrigues, o direito em vista só se extingue com a morte (CAHALI, 2007, p. 173). E, ainda, o artigo que confere a garantia habitacional ao cônjuge sobrevivente "não determina a sua resolução no caso de o beneficiário constituir nova família”. Portanto, se houvesse alguma restrição à constituição de uma nova família, tal vedação deveria ser convenientemente prevista na legislação vigente (RODRIGUES, 2006, p. 116). 
O assunto também emergiu na III Jornada de Direito Civil, oportunidade em que se consignou, por meio do Enunciado 271: "O cônjuge pode renunciar ao direito real de habitação, nos autos do inventário ou por escritura pública, sem prejuízo de sua participação na herança (BRASIL 2011).

Resta a hipótese de extinção do direito real de habitação em função do estabelecido no art. 1.410 do CC, eis que o benefício em análise deve seguir as regras pertinentes ao usufruto. Dessa forma, segundo o artigo suso mencionado, a extinção do direito ocorre com a morte do beneficiário, sem que possível sua transmissão aos próprios herdeiros.

\section{O DIREITO SUCESSÓRIO DOS COMPANHEIROS NO CÓDIGO CIVIL}

$\mathrm{Na}$ união estável, o direito sucessório do companheiro sobrevivente é regulado pelo art. 1.790 do CC, portanto, cabe ressaltar que ao companheiro supérstite não é deferido o direito a legítima, por não ser considerado herdeiro necessário, participando na sucessão apenas como sucessor regular.

Para que o companheiro possa figurar como herdeiro do falecido, é essencial que a união estável persista até a morte do autor da sucessão. Contudo, cabe elucidar que o instituto familiar em questão tem como sua principal característica a informalidade, "embora os conviventes possam ter celebrado um contrato escrito” (VELOSO, 2010, p. 167), não deixa de ser uma relação de fato, cujos requisitos estão indicados no art. 1.723 do CC: convivência notória, continua, duradoura e ânimo de constituir família. Além disso, o tempo que durou o relacionamento, ou a existência de filhos comuns, não importa para a sua caracterização (MONTEIRO, 2008, p. 98).

Ainda, para o reconhecimento da união estável, os companheiros não podem apresentar qualquer causa de impedimento matrimonial absoluto, definida pelo art. 1.521 do CC, salvo no que se refere às pessoas casadas que estiverem separadas de 
fato. Igualmente, os impedimentos constantes no art. 1.523 não são obstáculo para a sua formação, deixando claro que a união estável em momento algum pode ser confundida com o concubinato, já que, de acordo com a previsão do art. 1.727, "as relações não eventuais entre o homem e a mulher, impedidos de casar, constituem concubinato, e não geram os mesmos efeitos jurídicos da união estável”.

Uma leitura atenta do caput do at. 1.790 do CC evidencia que a sucessão do companheiro é limitada aos bens adquiridos onerosamente na vigência da união estável. Assim, denota-se que o convivente já é meeiro dos bens que constituíram sua quota-parte na herança do falecido, eis que, nos termos do art. 1.725 do mesmo código, o regime patrimonial de bens supletivo é o da comunhão parcial, ou seja, não havendo contrato entre os companheiros dispondo o contrário, a união é finda sob o regime legal (VELOSO, 2010, p. 168).

O regime de bens para o companheiro é totalmente irrelevante no plano sucessório, ao passo que sua existência como herdeiro está condicionada à "origem dos bens havidos pelo autor da herança” (OLIVEIRA, 2005, p. 164), ou seja, basta que tenham sido adquiridos onerosamente durante a convivência, sendo irrelevante a regência da comunhão parcial de bens, o pacto de regime diverso ou a "eventual titularidade do viúvo sobre parte deste acervo” (CAHALI, 2007, p. 182).

Nesse sentido, se na constância da união estável os conviventes não adquiriram nenhum bem a título oneroso, não há possibilidade de o companheiro participar na herança do falecido, mesmo que o de cujus tenha deixado um grande acervo patrimonial em função dos bens adquiridos antes da constituição da união estável (RODRIGUES, 2003, p. 182).

A par disso, no caso de a união estar submetida ao regime da separação de bens, embora seja uma hipótese excepcional, e o falecido ter adquirido bens onerosamente durante a união estável, o companheiro sobrevivente participa da herança quanto a estes, mesmo sendo bens particulares do de cujus. Logo, 
o companheiro só deixa de participar da repartição dos bens adquiridos anteriormente e dos contraídos a título gratuito, os quais caberão exclusivamente aos descendentes ou demais parentes sucessíveis (VELOSO, 2010, p. 173).

O inciso I do art. 1.790 do CC prevê a concorrência do companheiro com os filhos comuns do casal. Reza o referido dispositivo que o companheiro deverá receber a mesma porção hereditária que cabe a seus filhos. Já, sendo os descendentes apenas do autor da herança, terá direito a metade do que couber a cada um deles (inciso II, art. 1.790).

Zeno Veloso (2010, p. 175) assinala que na sucessão do companheiro não há regra que assegure a quota mínima de uma quarta parte da herança se for ascendente dos herdeiros com quem concorrer, diversamente do que é garantido ao cônjuge por meio da regra do art. 1.832 do CC.

A discussão doutrinária no que tange à concorrência do convivente supérstite com os descendentes, no entanto, gira em torno da conjetura de filiação híbrida, ou seja, a existência de filhos comuns dos companheiros concomitantemente a de exclusivos do falecido, que não é prevista na lei.

De acordo com Euclides de Oliveira (2005, p. 166), várias possibilidades para o partilhamento da herança são analisadas nesse caso, vez que é permitido considerar todos os filhos como se fossem comuns, ficando o companheiro com quota igual; como se todos fossem exclusivos, restringindo a quota do companheiro à metade; ou, ainda, à realização de um cálculo proporcional, mesclando "a quota igualitária com relação aos filhos comuns e só metade no que coubesse aos demais”.

Ressalta-se que a modalidade de cálculo misto não é cabível, já que geraria a diferenciação dos quinhões hereditários dos descendentes, o que, consequentemente, abalaria o princípio constitucional da igualdade entre os filhos e a regra expressa no art. 1.834 do CC, que não podem ambos ser descumpridos (VELOSO, 2010, p. 176). 
Francisco Cahali (2007, p. 184) adota o posicionamento que defende a aplicação do inciso I do art. 1.790 do diploma civil aos casos em tela, eis que a situação híbrida pode ser amparada em decorrência da amplitude do referido inciso, ao passo que não se encaixa ao previsto no inciso II do mesmo artigo, já que este estabelece expressamente a aplicação somente aos filhos do autor.

Em idêntica alheta, o Enunciado 226 (BRASIL, 2011) da III Jornada de Direito Civil, promovida pelo Conselho da Justiça Federal, constatou que: "Aplica-se o inc. I do art. 1.790 também na hipótese de concorrência do companheiro sobrevivente com outros descendentes comuns, e não apenas na concorrência com filhos comuns".

Zeno Veloso (2010, p. 176) avalia que, diante da concorrência do companheiro com filhos de origem comum e exclusiva do de cujus, deve prevalecer o disposto no inciso II do aludido artigo, isto porque, de seu ponto de vista, "os filhos do companheiro sobrevivente ainda têm a expectativa de herdar deste, enquanto os filhos que teve o falecido em outro relacionamento não têm essa esperança". Sendo assim, cabe ao convivente sobrevivo a metade do que foi conferido a cada um dos descendentes, para que não haja um maior prejuízo aos filhos exclusivos.

Determina o inciso III do art. 1.790 do CC que, na ausência de descendentes do falecido, o companheiro concorre com outros parentes sucessíveis, oportunidade esta que, em qualquer caso, receberá uma terça parte da herança.

A propósito, cabe esclarecer agora quem são os denominados outros parentes sucessíveis a que o citado inciso se refere e que, segundo Giselda Maria Fernandes Hironaka (2004, p. 100), deve-se recorrer à ordem de vocação hereditária, por meio dos art. 1.829 e seguinte do CC. São eles: os ascendentes, sem limitação de grau, seguidos pelos colaterais até o quarto grau.

Assim, estando vivos o pai e a mãe do de cujus, caberá um terço da herança para cada um deles e um terço para o companheiro. Se sobrevivente apenas um dos ascendentes, 
este irá receber dois terços da herança, enquanto o companheiro continua com a sua quota de um terço do acervo. Não importa com quantos ascendentes o companheiro irá concorrer, porquanto em todas as hipóteses este irá herdar apenas um terço do patrimônio hereditário. Por exemplo, mesmo que se trate de um parente distante que o falecido não mantinha muito contato, ele irá receber mais do que o convivente sobrevivo (2010, p. 178).

Para Euclides de Oliveira (2005, p. 172), a divisão da herança nos moldes acima descritos é insuficiente porque, mesmo que o companheiro "estivesse a concorrer com um filho, teria cota igual a deste, ou seja, metade da herança”, não fazendo sentido garantir a participação de parentes que possuem laços afetivos com o falecido menos estreitos do que o convivente.

\section{EXISTÊNCIA DE PATRIMÔNIO EXCLUSIVO DO COMPANHEIRO SOBREVIVENTE}

Enuncia o inciso IV do art. 1.790 do CC que a totalidade da herança somente é conferida ao companheiro sobrevivente se não houver herdeiros sucessíveis. Pois bem, sabendo-se que os parentes sucessíveis abrangem inclusive os colaterais até o quarto grau, dessa regra se infere que o companheiro só herdará todo o acervo se o falecido não deixou descendentes, ascendentes, nem colaterais até quarto grau (VELOSO, 2010, p. 182).

A partir desse raciocínio, o convivente "dividirá sua limitada herança com irmãos, tios ou até primos do falecido, os mais próximos colaterais excluindo os mais remotos" (CAHALI, 2007, p. 182), obedecida a mesma ordem de vocação hereditária prevista para o cônjuge.

A propósito, quadra lembrar a lição de Euclides de Oliveira (2005, p. 173), segundo a qual, pela disciplina do caput do art. 1.790 do CC, a participação do convivente sobrevivo na herança é limitada aos bens adquiridos onerosamente durante 
a união, e se não existirem bens nesta condição, não há como o companheiro receber alguma coisa.

Ainda, se não existirem herdeiros legitimados para o recebimento da herança, no que se refere ao patrimônio particular do de cujus, que em tese não pode ser repassado ao companheiro sobrevivente, os bens particulares do falecido são conferidos ao Poder Público - dependendo da circunscrição em que o bem esteja situado, ao município, ao Distrito Federal ou à União -, isto porque são arrecadados como herança jacente, convertida posteriormente em vacante, pois teoricamente não existem herdeiros passíveis de receber a herança (OLIVEIRA, 2005, p. 173).

Zeno Veloso (2010, p. 183), interpretando o inciso IV do art. 1.790 do CC, de forma diversa, analisa que tal disciplina estaria abrindo uma exceção ao que fora limitado pelo caput, pois a expressão "totalidade" exprime a intenção do legislador de conferir todo o patrimônio ao companheiro, inclusive o patrimônio particular, que em tese não estaria autorizado a receber.

Essa interpretação faz mais sentido quando se confronta a regra do art. 1.844 do mesmo diploma civil, que estabelece que a herança "só fica vacante e é devolvida ao poder público se não sobreviverem cônjuge ou companheiro nem parente algum sucessível, ou tendo eles renunciado à herança" (VELOSO, 2010, p.183). Logo, sendo certo que o companheiro que permanece vivo é considerado herdeiro do falecido, não se pode conceber que o acervo hereditário seja declarado vacante com existência de herdeiro do autor da herança.

Outro aspecto importante alude ao contido no art. 1.790, cuja disciplina não invoca o direito real de habitação em relação ao companheiro, como é garantido ao cônjuge sobrevivente.

Zeno Veloso (2010, p. 162), nesse ponto, conclui "que o legislador não quis conferir tal beneficio aos companheiros", já que regulou inteiramente a questão dos que vivem em união estável. Desta feita, deixando de mencionar o direito real de habitação, novamente, estabeleceu diferenciação entre os institutos do casamento e da união estável. 
Ocorre que os tribunais brasileiros, em especial a corte catarinense, têm conferido ao companheiro o direito real de habitação, desde que seja o único imóvel destinado a residência familiar, ante a justificativa de que o intuito do benefício é manter a família amparada economicamente, assegurando ao menos a moradia. Ressalta-se, inclusive, que é irrelevante se o imóvel foi adquirido antes da união estável, conforme decisão proferida pelo Tribunal de Justiça do Estado de Santa Catarina (TJSC, 2009), já que o direito real não se confunde com a meação da companheira ou companheiro.

Segue a mesma linha o Enunciado 117 (BRASIL, 2011) da I Jornada de Direito Civil, quando ratifica que a garantia habitacional prevista no art. 1.831 do CC deve ser também conferida ao companheiro, aplicada analogicamente em função do direito a moradia determinado pelo art. $6^{\circ}$ da CRFB.

Ainda, valida essa assertiva, o fato de que o direito real de habitação na união estável foi previsto pela Lei no 9.278/1996, a qual regula o $\S 3^{\circ}$ do art. 226 da CRFB, e esta não foi revogada, o que reforça o posicionamento da manutenção do benefício àqueles que conviviam em união estável nos mesmos moldes conferidos ao cônjuge supérstite.

\section{SUCESSÃO DOS COMPANHEIROS: INTERPRETAÇÃO DOUTRINÁRIA E JURISPRUDENCIAL}

A equiparação das entidades familiares surge como ponto controverso entre os estudiosos e, não raro, suscita dúvidas quanto à constitucionalidade da disciplina legal que regula a sucessão dos companheiros, principalmente, em função da isonomia das entidades familiares.

Apesar de muito criticado, o art. 1.790 do CC tem sido empregado aos casos concretos pelos tribunais brasileiros, de forma a seguir exatamente o que fora previsto na legislação correspondente à união estável. 
Em decisão proferida pelo STJ, o Ministro Fernando Gonçalves (STJ, 2008) afirma que a união estável não produz os mesmos efeitos que o casamento e, portanto, as alegações de que o companheiro deve ser comparado ao cônjuge sobrevivente são incabíveis, em face da diferença clarividente dos institutos em tela.

O ministro aduz, ainda, que a união estável possui legislação própria e esta deve ser aplicada, descabendo a analogia muitas vezes requerida, já que, "sob diversos e relevantes ângulos, há grandes e destacadas diferenças conceituais e jurídicas, de ordem teórica e de ordem prática, entre o casamento e a união estável”, dessa forma, não há que se falar em violação do princípio da isonomia (STJ, 2008).

Em idêntico diapasão foi o pronunciamento da $1^{\text {a }}$ Turma Cível do Tribunal de Justiça do Distrito Federal (TJDF, 2009). Para os tribunais que defendem a disciplina do art. 1.790 do diploma civilista, deve-se manter a regra que dita que os desiguais devem ser tratados de forma desigual, portanto impossível é conceder os direitos de um para outro.

Além disso, o Órgão Especial do Tribunal de Justiça do Rio Grande do Sul já prolatou decisão reconhecendo a aplicabilidade do citado art. 1.790 aos companheiros, ante o entendimento de que, diante da redação legislativa, restou claro que as determinações quanto à sucessão dos que viviam em união estável foi de plena escolha do legislador (TJRS, 2009).

Decisões no mesmo sentido, reiterando o posicionamento da não equiparação das entidades familiares, foram proferidas pelos Tribunais de Justiça de São Paulo (TJSP, 2009), Santa Catarina (TJSC, 20010) e Rio Grande do Sul (TJRS, 2010).

Apesar de existirem algumas divergências quanto ao quinhão hereditário destinado ao companheiro supérstite, o Tribunal de Justiça do Rio Grande do Sul tem julgado de acordo com a doutrina majoritária, ou seja, a aplicação do art. 1.790 do CC e seus incisos para a concorrência com os descen- 
dentes, dependendo se são descendentes comuns ou exclusivos do autor da herança, e ainda quanto à filiação híbrida, tem utilizado o inciso I do artigo anteriormente citado (TJRS, 2010).

Sob esse enfoque, já decidiu o STJ, no julgamento do Recurso Especial no 1090722/SP. Determinou a Corte Superior que, mesmo na ocorrência de uniões em que o regimento patrimonial da separação total de bens deveria ser empregado, por força do art. 1.641 do CC, para efeitos sucessórios são considerados todos os bens adquiridos na constância do casamento, tendo em vista que o regime patrimonial da união não importa, no que se refere ao art. 1.790 sub examine.

À união estável, portanto, aplica-se a presunção de que os bens adquiridos são provenientes do esforço comum, independente de provas, eis que a solidariedade é inerente à vida comum do casal e, "por si só, é fator contributivo para a aquisição dos frutos na constância de tal convivência” (STJ, 2010).

Salienta-se, contudo, que o ponto de grande discussão quanto à sucessão na união estável é a aplicação do inciso III do referido art. 1.790, onde é prevista a concorrência do companheiro sobrevivente com outros parentes sucessiveis, hipótese em que o companheiro herda no máximo um terço do patrimônio hereditário, limitado aos bens adquiridos na constância da união estável, como explanado anteriormente.

Por esse prisma, muitas decisões têm sido proferidas, no sentido de garantir a participação dos colaterais na sucessão proveniente da união estável. Na hipótese de o autor da herança possuir bens adquiridos anteriormente à união estável, este patrimônio não pode ser herdado pelo companheiro sobrevivente. Dessa forma, na ausência de descendentes e ascendentes do falecido, os bens adquiridos antes da união são destinados aos colaterais (TJSC, 2010).

A arguição de que em algumas situações a união estável pode ser mais benéfica do que o casamento já foi suscitada nos tribunais pátrios, ante a alegação de que, dependendo do regime de bens que este seguir, bem como se foram adquiridos bens na 
constância da união ou não, o companheiro poderia herdar um patrimônio maior do que se fosse ligado ao de cujus pelos laços do matrimônio (STJ, 2009).

OSTJ, contudo, já julgou no sentido de afastar tal alegação, levando em consideração a aplicação do art. 1.829 do CC outro raciocínio. A interpretação adotada pela Corte da Cidadania conferiu ao companheiro supérstite os mesmos direitos que seriam conferidos ao cônjuge. $\mathrm{O}$ que difere é simplesmente a utilização do artigo e a compreensão da disciplina nele contida (STJ, 2009).

Em rigor, não há como afirmar que a união informal entre o homem e a mulher poderia ser mais favorável, no que se refere à sucessão, do que as regras impostas ao casamento. Isto porque, a interpretação do artigo que determina a ordem de sucessão hereditária, a qual o cônjuge faz parte, possui diversas correntes. Logo, o que depende é a forma como é interpretada a norma, descabendo qualquer alegação de superioridade da união estável em relação ao instituto do casamento (STJ, 2009).

Zeno Veloso (2010, p. 178) considera que o artigo previsto pela lei civil, como regulador da sucessão na união estável, é um retrocesso evidente, pois a tendência da família contemporânea é estreitar, cada vez mais, os laços familiares. Com esse raciocínio, o autor afirma que descabe a sua aplicação, principalmente a regra contida no inciso III, porque os parentes colaterais na sucessão do art. 1.790 do CC seriam mais favorecidos do que os companheiros.

Como demonstrado anteriormente, as decisões dos tribunais brasileiros que versam sobre a sucessão na união estável buscam discutir a validade do inciso III do citado art. 1.790 porque, comparada a posição sucessória do cônjuge, o companheiro é colocado em patamar muito inferior.

Conforme destaca Zeno Veloso (2010, p. 178), já estava consolidado no direito sucessório brasileiro o entendimento de que "na falta de parentes em linha reta do falecido, o companheiro sobrevivente devia ser o herdeiro, afastando-se os colate- 
rais e o Estado”, em função de legislação civil pretérita - Lei no 8.971/1994 -, que previa a concessão da totalidade da herança ao companheiro, nestes casos.

O art. 1.829 do CC, no entanto, tem sido aplicado analogicamente à sucessão na união estável, garantindo aos companheiros as mesmas prerrogativas do cônjuge sobrevivente, sem deixar de levar em consideração os requisitos básicos para o reconhecimento da união estável.

Importante salientar que diversas decisões foram proferidas nesse sentido, nos Estados do Rio Grande do Sul (TJRS, 2009) e São Paulo (TJSP, 2011), ou seja, definiram que, em observância ao princípio da equidade, ao companheiro é garantido um melhor posicionamento na ordem de sucessão hereditária.

Nessa linha, já é pacífico que a solidariedade entre os conviventes está implícita na relação, portanto, inadmissível seria a hipótese de o companheiro ter de dividir o patrimônio do de cujus com, por exemplo, um tio distante, com quem não mantinha grande contato, tampouco possuía vínculo de afeto como o existente entre o falecido e a companheira, por exemplo.

Segundo Maria Berenice Dias (2011), também já se firmou entendimento no sentido de repudiar o preconceito aos companheiros, quando a sucessão, seja do cônjuge ou do companheiro, é regida pelo art. 1.829 do CC. Aduz a autora que o descompasso das previsões legislativas determinadas pelo art. 1.790 com a realidade fática deve ser considerado, eis que os participantes de qualquer entidade familiar assumem o dever de mútua assistência e participação na formação do patrimônio, razão pela qual o companheiro faz jus a mesma quota-parte que receberia o cônjuge.

Além disso, no julgamento do Recurso Especial $n^{\circ}$ 704637/RJ, em que atuou como relator o Ministro Luis Felipe Salomão, verifica-se que foi aplicada a analogia ao art. 1.829: os colaterais foram afastados da sucessão do de cujus e a herança destinada, em sua plenitude, à companheira, como se cônjuge fosse (STJ, 2009). 
$\mathrm{Na}$ decisão suso mencionada, foi garantida a totalidade da herança ao companheiro com base no art. $2^{\circ}$, inciso III, da Lei $\mathrm{n}^{\circ} 8.971 / 1994$, a qual regulava o direito dos companheiros a alimentos e a sucessão. Como a dita lei não foi revogada, o STJ entende que referida disciplina continua sendo passível de aplicação (STJ, 2011).

Contudo, a disciplina prevista na Lei no 8.971/1994 é a mesma que seria conferida ao cônjuge, na hipótese do inciso III do art. 1.829 do CC, caracterizando, assim, a analogia ao referido caso. Se em determinadas situações, cônjuges e companheiros são posicionados da mesma forma, não há por que distanciá-los, como faz o atual código civilista.

Para Zeno Veloso (2010, p. 164), não se pode admitir um tratamento desigual sobre o mesmo tema. Na avaliação do autor, não é valido conferir "vantagem ao companheiro sem o correspondente proveito ao cônjuge", o mesmo não pode acontecer para a situação contrária. Se tal ocorresse, haveria uma quebra da harmonia do sistema, tendo em vista que o casamento e a união estável "são entidades familiares, em idêntica altura, de igual importância e com a mesma dignidade".

A interpretação dada aos casos em que há nítida inferioridade do companheiro tem sido sanada pela jurisprudência dos tribunais, que vêm aplicando, de forma lógica, o que seria mais adequado para os que vivem em união estável, conforme os preceitos constitucionais e de modo construtivo e progressista (VELOSO, 2010, p. 164).

\section{A QUESTÃO DA (IN)CONSTITUCIONALIDADE DA SUCESSÃO NA UNIÃO ESTÁVEL}

A inconstitucionalidade do art. 1.790 do CC, regulador da sucessão na união estável, tem sido suscitada pela doutrina em função do estabelecido pelo $\S 3^{\circ}$ do art. 226 da CRFB, que reconhece a união informal como entidade familiar protegida pelo Estado, nos seguintes termos: "Para efeito da proteção do 
Estado, é reconhecida a união estável entre o homem e a mulher como entidade familiar, devendo a lei facilitar sua conversão em casamento".

O Tribunal de Justiça do Rio Grande do Sul adotou posicionamento em defesa da constitucionalidade do art. 1.790 do CC, na decisão que julgou improcedente, por maioria, o Incidente de Inconstitucionalidade no 70029390374, que tem servido de parâmetro para praticamente todas as decisões proferidas pela Corte gaúcha (TJRS, 2009).

O julgado suso mencionado concluiu que a CRFB não equiparou a união estável ao casamento, ante o argumento que: "atento à distinção constitucional, o Código Civil dispensou tratamento diverso" e que se trata "de regra criada pelo legislador ordinário no exercício do poder constitucional de disciplina das relações jurídicas patrimoniais decorrentes da união estável" (TJRS, 2009).

Assim, baseado no texto constitucional, essa corrente alega que são totalmente aplicáveis as regras estabelecidas na lei civil, por ausência de qualquer vício de inconstitucionalidade que as maculem, pois ao prever a conversão da união estável em casamento, o legislador deixou clara a sua intenção de manter os institutos de forma separada e desigual.

Restou sustentado, ainda, que a exclusão do companheiro do rol de herdeiros necessários tem como ponto de partida o fato de que nem todo cônjuge sobrevivente é herdeiro, portanto, não haveria ainda grandes distinções.

Já, sob outro vértice, Zeno Veloso (2010, p. 182-183) bem se posiciona ao defender que a família é constitucionalmente reconhecida como base da sociedade e, portanto, ostenta especial proteção estatal. As uniões estáveis são reconhecidas como entidades familiares, de forma que "estão praticamente equiparadas às famílias matrimonializadas e às que se criaram informalmente". Seguindo os ditames básicos para a caracterização da união estável, a diferenciação entre a posição sucessória do 
cônjuge sobrevivente e o companheiro supérstite, "além de contrariar o sentimento e as aspirações sociais, fere e maltrata, na letra e no espírito, os fundamentos constitucionais”.

Diversamente do que sustenta a Corte gaúcha, o Órgão Especial do Tribunal de Justiça do Estado do Paraná, ao julgar o Incidente de Inconstitucionalidade no 10472, manifestou-se pela inconstitucionalidade do dispositivo e considerou a aplicação do art. 1.790, inciso III, do CC, como uma ofensa ao art. 226, § 3, da CRFB (TJPR, 2009).

A Corte paranaense entendeu que o art. 1.790 do CC, além de infringir o disposto no art. 226, § 3o da CRFB, afronta os princípios da dignidade humana e da isonomia, devendo ser considerado regra retrógada, inaplicável e inconstitucional, do ponto de vista jurídico e social (TJPR, 2009).

É sabido que não cabe à lei infraconstitucional regular disposição da Carta Magna de forma diversa da que foi prevista, sob o risco de, no caso em tela, ser quebrado o princípio da igualdade, pois, em se tratando da disciplina do art. 226, § 3o, seu objetivo foi equalizar o casamento e a união estável por meio da elevação desta à estatura de entidade familiar, em decorrência de ambas as relações desempenharem o mesmo papel no desenvolvimento da família, base da sociedade.

Em idêntico diapasão, recentemente, o ministro Luis Felipe Salomão suscitou a inconstitucionalidade dos incisos III e IV do art. 1.790 do CC, designando sua apreciação à Corte Especial do STJ, eis que a matéria merece enfoque e exame aprofundados, levando em consideração a arguição formalizada e efetiva diferenciação do direito sucessório garantido à união estável (STJ, 2011).

A decisão foi prolatada em função de recurso proposto por companheira supérstite que requereu que lhe fosse conferida a totalidade da herança e o consequente afastamento dos colaterais, por força da questão que se refere à inconstitucionalidade do artigo regulador, neste caso (STJ, 2011). 
A promulgação do novo diploma civil, em 2002, emanou inúmeras alegações de retrocesso social com base no advento das Leis no 8.971/1994 e 9.278/1996, por meio das quais os companheiros e os cônjuges recebem tratamento igual em relação aos direitos sucessórios, como no caso da sucessão na propriedade, da titularidade do usufruto legal, e ainda ostentam titularidade para o direito real de habitação (HIRONAKA, 2009, p. 455).

Ora, se leis anteriores ao atual CC já previam normas garantindo os mesmos direitos a cônjuges e companheiros, em consonância com a CRFB, há total discrepância no modo como a matéria foi abordada, além do desrespeito ao princípio da proibição do retrocesso social (VELOSO, 2010, p. 183).

As conquistas alcançadas com a CRFB não podem ser ignoradas pela legislação infraconstitucional, a ponto de estabelecer disciplina contrária ao que já fora disposto. Quebrado o paradigma familiar anteriormente existente, a liberdade de escolha da formação familiar foi evidenciada e, por conseguinte, amparada pela Carta Magna brasileira, reconhecendo a existência de um vínculo tanto pessoal como patrimonial (DIAS, 2010, p. 68).

Por essa razão, a inconstitucionalidade do art. 1.790 do CC é almejada por grande parte da doutrina, em virtude de o dispositivo não estar de acordo com os preceitos legais, além de prever, de forma a inferiorizar, uma formação familiar que por direito já conquistara seu espaço na sociedade, bem como no mundo jurídico.

Para Giselda Maria Fernandes Novaes Hironaka (2004, p. 455) o CC provoca, em virtude de sua redação, grande insegurança e "impressões de injustiça" nos julgados proferidos por todo o país, "trazendo soluções diferentes para situações fáticas iguais".

Euclides de Oliveira (2005, p. 164) afirma que flagrantemente se identifica o caráter discriminatório do direito sucessório do companheiro em comparação com a posição reservada ao cônjuge. Também se denota que foi apenas na esfera da 
sucessão hereditária que o legislador resolveu criar certa diferenciação, tendo em vista que "para fins de alimentos e de meação, o companheiro se situa em posição confortável, similar à reservada por lei ao cônjuge".

A par disso, Maria Berenice Dias (2011) diz que a manutenção da não equiparação dos institutos familiares pelos tribunais pátrios desrespeita a "diretriz traçada pela Constituição Federal, que não estabeleceu qualquer hierarquização entre as entidades familiares", apenas as elencou de forma exemplificativa.

Arnaldo Rizzardo (2009, p. 199) anota que "desde o momento em que a ordem constitucional reconheceu a união estável como entidade familiar, evidente que o alcance atinge os direitos patrimoniais”, apesar de que as diferenciações trazidas pela lei deixam clara a desigualdade estabelecida na ordem de vocação dos companheiros.

De acordo com Zeno Veloso (2010, p. 159), a CRFB, ao prever que a lei deve facilitar a conversão da união estável em casamento, "não está estabelecendo hierarquia, precedência ou preferência” entre elas, mas tão somente dispensando os que já vivem em união estável de certas exigências que são prescritas para os que desejam casar-se. Conclui o doutrinador que uma interpretação diversa entraria em choque com os próprios fundamentos constitucionais, vez que o propósito é apenas auxiliar o modelo familiar denominado união estável.

Por derradeiro, cumpre anotar que é da função da lei acompanhar as transformações que as famílias foram sofrendo ao longo dos séculos; a família mudou e, consequentemente, "para que não perca seu sentido maior, que é o da proteção da sociedade e das pessoas” (HIRONAKA, 2009), p. 456), é que a alteração legislativa se torna essencial para o desenvolvimento e evolução contínua da sociedade. 


\section{CONCLUSÃO}

A busca pela aplicação das mesmas prerrogativas garantidas ao cônjuge sobrevivente aos companheiros é frequente no Poder Judiciário, com suas decisões alicerçadas na equiparação constitucional da união estável como entidade familiar, quando, obviamente, estão presentes os requisitos básicos para o seu reconhecimento: convivência duradoura, pública, contínua e que tenha o objetivo de constituir família.

Como demonstrado pelas decisões apresentadas no presente artigo, os eminentes julgadores desempenham seu papel na tentativa de amenizar o descompasso da legislação atual com a realidade da sociedade, o que mais uma vez comprova a evidente infração ao texto constitucional.

Em conclusão, não há como não declarar a inconstitucionalidade do art. 1.790 do CC, já que suas previsões vão de encontro ao que é definido por lei de máximo patamar - a Carta Magna -, restando tão só a possibilidade de aplicação do direito sucessório de forma equalizada a cônjuges e companheiros, por meio da utilização analógica do art. 1.829 do diploma civilista ao companheiro, ou, quiçá, mediante a criação de nova lei que abarque todas as entidades familiares.

Abstract: The theme of this article belongs to the inheritance law area, especially the succession of partners who live in a common-law marriage, as a family relationship recognized by the brazilian constitutional order since 1988, however in doctrine as in jurisprudence the partner's participation on the division of the estate of the deceased is not unanimous. In this context, this research aims to identify if the succession of the partners is a violation to the constitutional provisions, considering the unequal treatment between marriage and common-law marriage in the realm of inheritance law.

Keywords: Common law marriage. Matrimony. Inheritance law. (Un)constitutionality. 


\section{REFERÊNCIAS}

BASTOS, Celso Ribeiro; MARTINS, Ives Gandra. Comentários à Constituição Federal do Brasil. São Paulo: Saraiva, 1989. v. 2.

BONAVIDES, Paulo; MIRANDA, Jorge; AGRA, Walber de Moura.

Comentários à Constituição Federal de 1988. Rio de Janeiro: Forense, 2009.

BRASIL. Conselho de Justiça Federal. Enunciado 117, I Jornada de Direito Civil. Disponível em: <http://daleth.cjf.jus.br/revista/enunciados/ IJornada.pdf>. Acesso em: 2 maio 2011.

BRASIL. Conselho de Justiça Federal. Enunciado 226, III Jornada de Direito Civil. Disponível em: <http://daleth.cjf.jus.br/revista/enunciados/ IIIJornada.pdf>. Acesso em: 2 maio 2011.

BRASIL. Conselho de Justiça Federal. Enunciado 270. III Jornada de Direito Civil. Disponível em: <http://daleth.cjf.jus.br/revista/enunciados/ IIIJornada.pdf>. Acesso em: 2 maio 2011.

BRASIL. Conselho de Justiça Federal. Enunciado 271, III Jornada de Direito Civil. Disponível em: <http://daleth.cjf.jus.br/revista/enunciados/ IIIJornada.pdf $>$. Acesso em: 2 maio 2011.

BRASIL. Constituição (1988). Constituição da República Federativa do Brasil de 1998. Disponível em: 〈http://www.planalto.gov.br>. Acesso em: 4 junho 2011.

BRASIL. Lei $n^{\circ}$ 8.971, de 29 de dezembro de 1994. Regula os direitos dos companheiros a alimentos e à sucessão. Disponível em: <http://www. planalto.gov.br>. Acesso em: 4 junho 2011.

BRASIL. Lei $n^{\circ}$ 9.278, de 10 de maio de 1996. Regula o $\$ 3^{\circ}$ do art. 226 da Constituição Federal. Disponível em: 〈http://www.planalto.gov.br〉. Acesso em: 4 junho 2011.

BRASIL. Lei no 10.406, de 10 de janeiro de 2002. Código Civil. Disponível em: 〈http://www.planalto.gov.br>. Acesso em: 4 junho 2011.

BRASIL. Supremo Tribunal Federal. ADI no 4277. Relator Min. Ayres Britto. Brasília,DF. Julgado em: 5-5-2011. Disponível em: <http://www.stf. jus.br>. Acesso em: 4 abr. 2011.

BRASIL. Superior Tribunal de Justiça. AI no Recurso Especial n. 1135354, Relator Min. Luis Felipe Salomão. Brasília,DF. Julgado em: 27-5-2011. Disponível em: <http://www.stj.jus.br>. Acesso em: 3 jun 2011. 
BRASIL. Superior Tribunal de Justiça. EREsp 736627/PR. Relator Min. Fernando Gonçalves. Brasília,DF. Julgado em: 25-2-2008. Disponível em: < http://www.stj.jus.br>. Acesso em: 4 maio 2011.

BRASIL. Superior Tribunal de Justiça. REsp 704637/RJ, Relator Min. Luis Felipe Salomão. Brasília,DF. Julgado em: 17-3-2011. Disponível em: <http://www.stj.jus.br>. Acesso em: 15 maio 2011.

BRASIL. Superior Tribunal de Justiça. REsp 1090722/SP. Relator Min. Massami Uyeda. Brasília,DF. Julgado em: 2-3-2010. Disponível em: <http:// www.stj.jus.br>. Acesso em: 10 maio 2011.

BRASIL. Superior Tribunal de Justiça. REsp 1117563/SP. Relatora Min. Nancy Andrighi. Brasília,DF. Julgado em: 17-12-2009. Disponível em: <http://www.stj.jus.br>. Acesso em: 28 abr. 2011.

CAHALI, Francisco José. Sucessão decorrente do casamento e da união estável. In: ; HIRONAKA, Giselda Maria Fernandes Novaes. Direito das sucessões. 3. ed. São Paulo: RT, 2007.

. Sucessão legítima. In: CAHALI, Francisco José; HIRONAKA, Giselda Maria Fernandes Novaes. Direito das sucessões. 3. ed. São Paulo: RT, 2007.

CANOTILHO, J.J. Gomes. Direito constitucional e a teoria da constituição. 7. ed. Coimbra: Almedina, 2004.

COMPLAK, Krystian. Cinco teses sobre a dignidade da pessoa humana como conceito jurídico. Revista da ESMESC, Florianópolis, ESMESC, v. 1, n.1, p. 107-120, ago. 1995.

DIAS, Maria Berenice. Manual de direito das famílias. 6. ed. São Paulo: RT, 2010 .

. Filhos, bens e amor não combinam. Disponível em: <http://www. mariaberenicedias.com.br/uploads/3__filhos_bens_e_amor_n\%E3o_ combinam.pdf>. Acesso em: 25 abr. 2011.

. Ponto final. Disponível em: <http://www.mariaberenicedias.com. br/uploads/2__ponto_final.pdf>. Acesso em: 2 maio 2011.

.; PEREIRA, Rodrigo da Cunha (Coords.). Direito de família e o Novo Código Civil. 4. ed. Belo Horizonte: Del Rey, 2006.

DIMOULIS, Dimitri. Teoria geral dos direitos fundamentais. São Paulo: Revista dos Tribunais, 2008. 
DISTRITO FEDERAL. Tribunal de Justiça. Apelação Cível n. 2009.00.2.001862-2, AC 355.492. Relator Des. Natanael Caetano. Brasília, DF. Julgado em: 29-4-2009. Disponível em: 〈http://www.tjdft.jus.br>. Acesso em: 4 maio 2011.

DINIZ, Maria Helena. Curso de direito civil brasileiro: direito de família. 24. ed. São Paulo: Saraiva, 2009. v. 5. . Curso de direito civil brasileiro: direito das sucessões. 24. ed. São Paulo: Saraiva, 2010. v. 6.

FONTANELLA, Patrícia. União estável: a eficácia temporal das leis regulamentadoras. 2. ed. Florianópolis: Ed. OAB/SC, 2006.

GONÇALVES, Carlos Roberto. Direito civil brasileiro: direito de família. 6. ed. São Paulo: Saraiva, 2009. v. 6.

HIRONAKA, Giselda Maria Fernandes Novaes. Ordem de vocação hereditária. In: ; PEREIRA, Rodrigo da Cunha (Coords.). Direito das sucessões e o Novo Código Civil. Belo Horizonte: Del Rey, 2004. p. 89-104.

; TARTUCE, Flávio; SIMÃO, José Fernandes (Coods.). Direito de família e das sucessões. São Paulo: Método, 2009.

LEITE, Eduardo de Oliveira. Direito civil aplicado: direito das sucessões. 2. ed. São Paulo: RT, 2004. v. 6.

LÔBO, Paulo. Direito civil: famílias. São Paulo: Saraiva, 2008.

MADALENO, Rolf. A concorrência sucessória e o trânsito processual: a culpa mortuária. Revista Brasileira de Direito de Família. Porto Alegre, Síntese/IBDFam, ano 7, n. 29, p. 141, abr./maio 2005.

MONTEIRO, Washington de Barros. Curso de direito civil: direito das sucessões. 36. ed. São Paulo: Saraiva, 2008. v. 6.

; SILVA, Regina Beatriz Tavares da. Curso de direito civil: direito de família. 39. ed. São Paulo: Saraiva, 2009. v. 2.

MORAES, Alexandre de. Constituição do Brasil interpretada e legislação constitucional. 6. ed. São Paulo: Atlas, 2006.

OLIVEIRA, Euclides de. União estável: do concubinato ao casamento. 6. ed. São Paulo: Método, 2003. 
2005.

. Direito de herança: a nova ordem da sucessão. São Paulo: Saraiva,

PARANÁ. Tribunal de Justiça. Incidente de Inconstitucionalidade n. 10472.

Relator Des. Sérgio Arenhart. Curitiba,PR. Julgado em: 4-12-2009.

Disponível em: 〈http://www.tjpr.jus.br〉. Acesso em: 15 maio 2011.

PERROT, Michelle. O nó e o ninho. Revista Veja 25 anos: reflexões para o futuro. São Paulo, Abril, 1993.

RIO GRANDE DO SUL. Tribunal de Justiça. Agravo de Instrumento No 70014145973. Relator Des. Luiz Felipe Brasil Santos. Porto Alegre, RS. Julgado em: 25-1-2006. Disponível em: <http://www.tjrs.jus.br>. Acesso em: 4 maio 2011.

RIO GRANDE DO SUL. Tribunal de Justiça. Agravo de Instrumento n. 70018904763, de Ijuí. Relator Des. Ricardo Raupp Ruschel. Porto Alegre,RS. Julgado em: 23-5-2007. Disponível em: 〈http://www.tjrs.jus.br>. Acesso em: 6 maio 2011.

RIO GRANDE DO SUL. Tribunal de Justiça. Agravo de Instrumento n. 70024715104, de Farroupilha. Relator Des. José Ataídes Siqueira Trindade. Porto Alegre,RS. Julgado em: 7-8-2008. Disponível em: < http://www.tjrs. jus.br>. Acesso em: 13 maio 2011.

RIO GRANDE DO SUL. Tribunal de Justiça. Agravo de instrumento $n$. 70024968349, de São Sebastião do Caí. Relator Des. Luiz Ari Azambuja Ramos. Porto Alegre,RS. Julgado em: 23-3-2010. Disponível em: <http:// www.tjrs.jus.br>. Acesso em: 15 maio 2011.

RIO GRANDE DO SUL. Tribunal de Justiça. Agravo de Instrumento n. 70032581530, de Santa Maria. Rel. Des. Claudir Fidelis Faccenda. Julgado em: 17-12-2009. Disponível em: 〈http://www.tjrs.jus.br〉. Acesso em: 12 maio 2011.

RIO GRANDE DO SUL. Tribunal de Justiça. Apelação civel n.

70036339158, de Camaquã. Relator Des. Luiz Ari Azambuja Ramos. Porto Alegre,RS. Julgado em: 12-8-2010. Disponível em: 〈http://www.tjrs.jus.br>. Acesso em: 12 maio 2011.

RIO GRANDE DO SUL. Tribunal de Justiça. Agravo de Instrumento n. 70037097151, de Porto Alegre. Relator Des. Jorge Luís Dall'Agnol. Porto Alegre,RS. Julgado em: 7-7-2010. Disponível em: 〈http://www.tjrs.jus.br〉. Acesso em: 12 maio 2011. 
RIO GRANDE DO SUL. Tribunal de Justiça. Agravo de Instrumento n. 70037502127, de Gravataí. Relator Des. Jorge Luís Dall'Agnol. Porto Alegre,RS. Julgado em: 16-12-2010. Disponível em: < http://www.tjrs.jus. br>. Acesso em: 6 maio 2011.

RIO GRANDE DO SUL. Tribunal de Justiça. Apelação civel n. 70029885456, de Santa Bárbara do Sul. Relator Des. Ricardo Raupp Ruschel. Porto Alegre,RS. Julgado em: 22-7-2009. Disponível em: <http:// www.tjrs.jus.br>. Acesso em: 13 maio 2011.

RIO GRANDE DO SUL. Tribunal de Justiça. Apelação civel n. 70030157820, de Porto Alegre. Relator Des. José Conrado Kurtz de Souza. Porto Alegre,RS. Julgado em: 22-7-2009. Disponível em: <http://www.tjrs. jus.br>. Acesso em: 13 maio 2011.

RIO GRANDE DO SUL. Tribunal de Justiça. Apelação civel n. 70036339158, de Camaquã. Relator Des. Luiz Ari Azambuja Ramos. Porto Alegre,RS. Julgado em: 12-8-2010. Disponível em: 〈http://www.tjrs.jus.br〉. Acesso em: 12 maio 2011.

RIO GRANDE DO SUL. Tribunal de Justiça. Embargos Infringentes n. 70027265545, de Antônio Prado. Relator Des. André Luiz Planella Villarinho. Porto Alegre,RS. Julgado em: 10-7-2009. Disponível em: <http://www.tjrs.jus.br>. Acesso em: 15 maio 2011.

RIO GRANDE DO SUL. Tribunal de Justiça. Embargos Infringentes n. 70032120735, de Santa Bárbara do Sul. Relator Des. Rui Portanova. Porto Alegre,RS. Julgado em: 12-3-2010. Disponível em: 〈http://www.tjrs.jus.br>. Acesso em: 6 maio 2011.

RIO GRANDE DO SUL. Tribunal de Justiça. Embargos Infringentes n. 70032516148. Relator Des. José Ataídes Siqueira Trindade. Porto Alegre, RS. Julgado em: 11-12-2009. Disponível em: 〈http://www.tjrs.jus.br>. Acesso em: 4 maio 2011.

RIO GRANDE DO SUL. Tribunal de Justiça. Embargos Infringentes n. 70038442166. Relator Des. Sérgio Fernando de Vasconcellos Chaves. Porto Alegre, RS. Julgado em: 8-10-2010. Disponível em: <http://www.tjrs.jus. br>. Acesso em: 4 maio 2011.

RIO GRANDE DO SUL. Tribunal de Justiça. Incidente de Inconstitucionalidade n. 70029390374, de Porto Alegre. Relator Des. Leo Lima. Porto Alegre,RS. Julgado em: 9-11-2009. Disponível em: <http:// www.tjrs.jus.br>. Acesso em: 4 maio 2011. 
RIZZARDO, Arnaldo. Direito de família. 5. ed. Rio de Janeiro: Forense, 2007.

. Direito das sucessões. 5. ed. Rio de Janeiro: Forense, 2009.

RODRIGUES, Silvio. Direito civil: direito das sucessões. 26. ed. São Paulo: Saraiva, 2003. v. 7.

SANTA CATARINA. Tribunal de Justiça. Apelação Cível n. 2006.022719-2, de Cunha Porã. Relator Des. Gilberto Gomes de Oliveira. Florianópolis,SC. Julgado em: 14-12-2010. Disponível em: <http://www. tj.sc.gov.br>. Acesso em: 15 maio 2011..

SANTA CATARINA. Tribunal de Justiça. Apelação Cível n. 2008.001068-9, de Joinville. Relator Des. Juiz Henry Petry Junior. Florianópolis,SC. Julgado em: 8-6-2009. Disponível em: <http://www.tj.sc.gov.br>. Acesso em: 29 abr. 2011.

SANTA CATARINA. Tribunal de Justiça. Agravo de Instrumento n. 2010.009821-9, de Itapema. Relator Des. Maria do Rocio Luz Santa Ritta. Florianópolis, SC. Julgado em: 8-11-2010. Disponível em: <http://www. tj.sc.gov.br>. Acesso em: 4 maio 2011.

SÃO PAULO. Tribunal de Justiça. Agravo de Instrumento n. 0367575 40.2009.8.26.0000, de São Paulo. Relator Des. Piva Rodrigues. São Paulo,SP. Julgado em: 15-2-2011. Disponível em: 〈http://www.tj.sp.gov.br〉. Acesso em: 15 maio 2011.

SÃO PAULO. Tribunal de Justiça. Agravo de Instrumento n. 0015728 09.2008.8.26.0000, de Bragança Paulista. Relator Des. Morato de Andrade. São Paulo, SP. Julgado em: 3-2-2009. Disponível em: <http://www.tj.sp.gov. br> Acesso em: 4 maio 2011.

SÃO PAULO. Tribunal de Justiça. Agravo de Instrumento n. 0133163. 33.2010.8.26.0000, de Barretos. Relator Des. Paulo Eduardo Razuk. São Paulo,SP. Julgado em: 17-8-2010. Disponível em: 〈http://www.tj.sp.gov.br〉. Acesso em: 14 maio 2011.

SÃO PAULO. Tribunal de Justiça. Agravo de Instrumento n. 9038173. 28.2009.8.26.0000, de São Bernardo do Campo. Relator Des. Fortes Barbosa. São Paulo,SP. Julgado em: 23-3-2011. Disponível em: <http:// www.tj.sp.gov.br>. Acesso em: 14 maio 2011. 
SÃO PAULO. Tribunal de Justiça. Agravo de Instrumento n. 9040850. 31.2009.8.26.0000, de Atibaia. Relatora Des. Viviani Nicolau. São Paulo,SP. Julgado em: 9-11-2010. Disponível em: 〈http://www.tj.sp.gov.br〉. Acesso em: 14 maio 2011.

SÃO PAULO. Tribunal de Justiça. Apelação Cível n. 0287356 -

40.2009.8.26.0000, de Pirassununga. Relator Des. Sebastião Carlos Garcia. São Paulo,SP. Julgado em: 28-4-2011. Disponível em: <http://www.tj.sp.gov. br>. Acesso em: 14 maio 2011.

SARLET, Ingo Wolfgang. A eficácia dos direitos fundamentais. 4. ed. Porto Alegre: Livraria do Advogado, 2004.

- Dignidade da pessoa humana e direitos fundamentais. 3. ed. Porto Alegre: Livraria do Advogado, 2004.

SILVA, José Afonso da. Curso de direito constitucional positivo. 23. ed. São Paulo: Malheiros, 2004. .

. Comentário contextual à Constituição. 5. ed. São Paulo: Malheiros, 2008.

TARTUCE, Flávio; SIMÃO, José Afonso. Direito civil: direito de família. 3. ed. São Paulo: Método, 2008. v. 5.

VELOSO, Zeno. Direito hereditário do cônjuge e do companheiro. São Paulo: Saraiva, 2010.

VENOSA, Sílvio de Salvo. Direito civil: direito das sucessões. 10. ed. São Paulo: Atlas, 2010. v. 7.

WALD, Arnoldo. Direito das sucessões. 12. ed. São Paulo: Saraiva, 2002. . O novo direito das sucessões. 13. ed. São Paulo: Saraiva, 2007. . Direito civil: direito de família. 17. ed. São Paulo: Saraiva, 2009. v. 5. 